\title{
Immunolocalization of Inhibin/Activin Subunit Proteins During the Breeding Season in Testes and Scented Glands of Muskrats (Ondatra zibethicus)
}

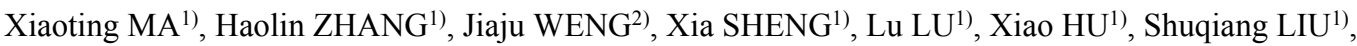 \\ Meiyu XU' ${ }^{1)}$, Qiang WENG ${ }^{1,3) *}$, Gen WATANABE ${ }^{3,4}$ and Kazuyoshi TAYA ${ }^{3,4}$ \\ ${ }^{1)}$ College of Biological Science and Technology, Beijing Forestry University, Beijing 100083, ${ }^{2}$ School of Basic Medical Sciences, Peking \\ University, Beijing 100083, PR China, ${ }^{3)}$ Laboratory of Veterinary Physiology, Tokyo University of Agriculture and Technology, Tokyo \\ 183-8509 and ${ }^{4)}$ United Graduate School of Veterinary Sciences, Gifu University, Gifu 501-1193, Japan
}

(Received 1 November 2010/Accepted 20 April 2011/Published online in J-STAGE 2 May 2011)

ABSTRACT. The objective of this study was to investigate the cellular immunolocalization of inhibin $\alpha$ and inhibin/activin $\left(\beta_{\mathrm{A}}\right.$ and $\left.\beta_{\mathrm{B}}\right)$ subunits in the muskrat testes and scented glands during the breeding season. Inhibin $\alpha$ and inhibin/activin $\left(\beta_{\mathrm{A}}\right.$ and $\left.\beta_{\mathrm{B}}\right)$ subunits were expressed in Sertoli cells and Leydig cells of testes and glandular cells of scented glands, respectively. Also, positive signals of inhibin $\alpha$ and inhibin/activin $\left(\beta_{\mathrm{A}}\right.$ and $\left.\beta_{\mathrm{B}}\right)$ subunits by Western blotting were both observed in testicular and scented glandular tissues. These results suggested that the testes and scented glands of the muskrats had the ability to synthesize inhibins and activins and that activins and inhibins might play an important role in testicular and scented glandular function in muskrats.

KEY WORDS: activin, inhibin, muskrat, scented gland, testes.

J. Vet. Med. Sci. 73(9): 1199-1205, 2011

Inhibins and activins are growth and differentiation factors that have been localized in both the reproductive and nonreproductive organs. They exert their effects through both endocrine and local (autocrine/paracrine) mechanisms [18]. Inhibins and activins are structurally related dimeric gonadal proteins with the ability to regulate follicle-stimulating hormone (FSH) secretion from the pituitary glands $[26,27]$. They are dimeric glycoproteins formed by two of three different subunits $\left(\alpha, \beta_{\mathrm{A}}\right.$ and $\left.\beta_{\mathrm{B}}\right)$. Inhibins consist of either of the $\beta$-subunits dimerized with a common $\alpha$-subunit $\left(\alpha-\beta_{A}\right.$ and $\alpha-\beta_{B}$; inhibin $A$ and inhibin $B$, respectively). Activins are dimers of $\beta$-subunits $\left(\beta_{A}-\beta_{A}, \beta_{A}-\beta_{B}\right.$ and $\beta_{B}-\beta_{B}$; activin $A$, activin $A B$ and activin $B$, respectively). In mammalian species, apart from their action on FSH secretion, inhibins and activins have been shown to exert paracrine/ autocrine effects within the gonads [3, 12, 23, 31, 32] and other tissues [22] and have been proposed to have an important autocrine/paracrine function during cells growth [35]. The testis is not the only source of inhibins and activins in the male reproductive tract, and there are several reports of inhibin/activin subunit mRNA and protein expression in the prostate, seminal vesicles and epididymis [20]. Recent reports indicated that these proteins were shown subsequently to affect a range of tissues and systems beyond their role in reproduction $[1,11,19]$.

The muskrat (Ondatra zibethicus) is a medium sized, semiaquatic rodent that lives throughout Canada and the United States and in some parts of northern Mexico. It gets its name from the two scented glands near its tail that give off a musky odor [29]. The muskrat is a seasonal breeder with a sexually active period of about 8 months from March

\footnotetext{
* Correspondence to: Weng, Q., Laboratory of Animal Physiology, College of Biological Science and Technology, Beijing Forestry University, Beijing 100083, People's Republic of China. e-mail: qiangweng@bjfu.edu.cn
}

to October. During the breeding period, the male muskrat is willing to mate and produces mature spermatozoa, and at the same time, the scented glands secrete perfume substances that are used as expensive traditional Chinese medicines [4]. In this study, we investigated the expression of inhibin/ activin subunits during the breeding season in testes and scented glands of the muskrat. The aim of the present study was to elucidate inhibins and activins as endocrine or paracrine/autocrine factors that play a physiological role in testicular and scented glandular function in muskrats.

Nine adult muskrats were obtained in March $(n=3)$, May $(n=3)$ and July $(n=3) 2010$ from Xichuan Wangnong Muskrats Breeding Farm, Beijing, China (Fig. 1). One male and one female muskrat were kept in each enclosure. All the animals were treated in accordance with the National Animal Welfare Legislation. All experimental procedures were carried out in accordance with the guidelines established by the Beijing Forestry University. Each pair of testicular and scented glandular tissues was obtained from each muskrat. The testis and scented gland from one side were immediately fixed for $12 \mathrm{hr}$ in Bouin's solution or 4\% paraformaldehyde (Sigma Chemical Co., St. Louis, MO, U.S.A.) in $0.05 \mathrm{M} \mathrm{PBS}, \mathrm{pH} \mathrm{7.4,} \mathrm{for} \mathrm{histological} \mathrm{and} \mathrm{immuno-}$ histochemical observations; the testis and scented gland from the other side were immediately stored at $-80^{\circ} \mathrm{C}$ until they were used for Western blotting detection.

The testicular and scented glandular specimens were dehydrated in an ethanol series and embedded in paraffin wax. Serial sections $(4 \mu \mathrm{m})$ were mounted on slides coated with poly-L-lysine (Sigma, St. Louis, MO, U.S.A.). Some sections were stained with hematoxylin-eosin (HE) for observations of general histology.

The serial sections of testes and scented glands were incubated with $10 \%$ normal goat serum to reduce background staining caused by the second antibody. The sec- 

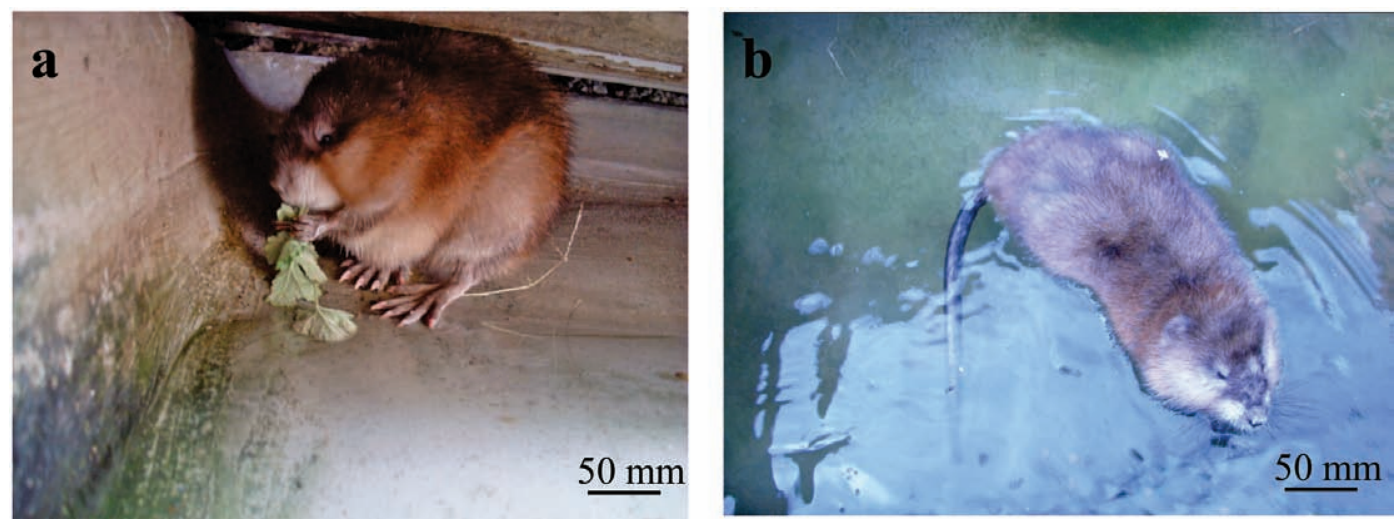

Fig. 1. The Muskrat (Ondatra zibethicus) is a medium sized, semiaquatic rodent that gets its name from the 2 scented glands near its tail that give off a musky odor. During the breeding period, the male muskrat scented glands secrete perfume substances that are used as expensive traditional Chinese medicines. (a) feeding muskrat, (b) swimming muskrat.
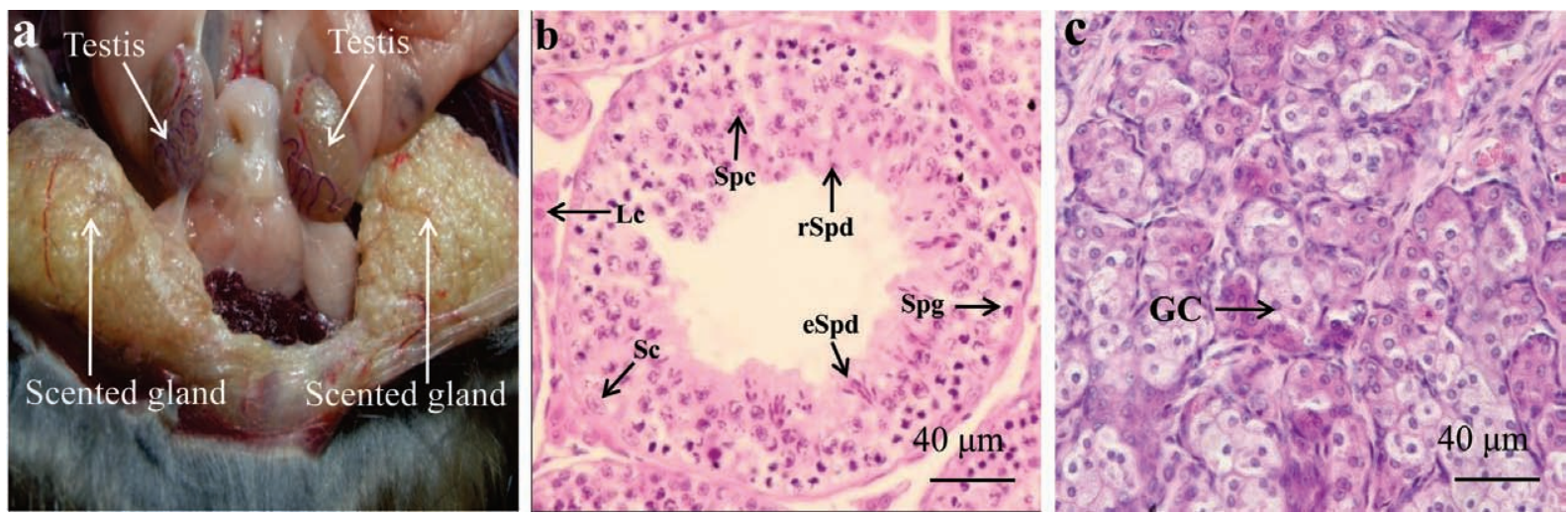

Fig. 2. Morphological localization of the muskrat testes and scented glands and the histologic structures of the testes and scented glands by hematoxylin-eosin staining (HE). a) The testes and scented glands of the muskrat. b) The entire spermatogenic population from spermatogonia (Spg) to elongate spermatids (eSpd) was observed in seminiferous tubules. c) Glandular cells were found in scented glands of the muskrat. Lc, Leydig cell; Sc, Sertoli cell; Spg, spermatogonia; Spc, spermatocyte; rSpd, round spermatid; eSpd, elongate spermatid; GC, glandular cell. Bar: $40 \mu \mathrm{m}$.

tions were then incubated with primary antibody $(1: 1,000$ or $1: 2,000)$ raised against porcine inhibin $\alpha$ chain $(1-30)-\mathrm{NH}_{2}$ conjugated to rabbit serum albumin, porcine inhibin/activin $\beta_{\mathrm{A}}(81-113)-\mathrm{NH}_{2}(\# 305-24 \mathrm{D})$ [30] and cyclic acetyl human inhibin/activin $\beta_{\mathrm{B}}(81-113)-\mathrm{NH}_{2}(\# 305-25 \mathrm{D})$ [30] for $12 \mathrm{hr}$ at room temperature. The sections were then incubated with a second antibody, goat anti-rabbit $\lg$ conjugated with biotin and peroxidase with avidin, using a rabbit ExtrAvidin $^{\mathrm{TM}}$ staining kit (Sigma, St. Louis, MO, U.S.A.), followed by visualizing with $30 \mathrm{mg}$ 3,3-diaminobenzidine (Wako, Tokyo, Japan) solution in $150 \mathrm{ml}$ of 0.05 mol Tris- $\mathrm{HCl} \mathrm{l}^{-1}$ buffer, pH 7.6, plus $30 \mu l \mathrm{H}_{2} \mathrm{O}_{2}$. Finally, the reacted sections were counterstained with hematoxylin solution (Merck, Tokyo, Japan). The control sections were treated with normal rabbit serum (Sigma, St. Louis, MO, U.S.A.) instead of the primary antisera. The specificity of the inhibin $\alpha$ and inhibin/activin $\left(\beta_{\mathrm{A}}\right.$ and $\left.\beta_{\mathrm{B}}\right)$ subunits has been described for rat [17] and golden hamster testes [10] and for wild ground squirrels [21].

The testicular and scented glandular tissues were weighed and diced into small pieces using a clean razor blade. The tissues were homogenized in a homogenizer containing 300 $\mu l$ of $10 \mathrm{mg} / \mathrm{m} l$ PMSF stock and incubated on ice for $30 \mathrm{~min}$ while maintaining the temperature at $4^{\circ} \mathrm{C}$ throughout all the procedures. Homogenates were centrifuged at $12,000 \times \mathrm{g}$ for $10 \mathrm{~min}$ at $4^{\circ} \mathrm{C}$. Protein extracts $(25 \mu \mathrm{g})$ were mixed with an equal volume of $2 \times$ Laemmli sample buffer. Equal amounts of each sample were loaded and run on a $12 \%$ SDS-PAGE gel at $18 \mathrm{~V} / \mathrm{cm}$ and transferred to nitrocellulose membranes using a wet transblotting apparatus (Bio-Rad, Richmond, CA, .U.S.A.). The membranes were blocked in $3 \%$ BSA for $1 \mathrm{hr}$ at room temperature. Primary incubation of the membranes was carried out using a 1:1,000 dilution of primary antibody raised against porcine inhibin $\alpha$ chain (130) $-\mathrm{NH}_{2}$ conjugated to rabbit serum albumin, porcine inhibin/activin $\beta_{\mathrm{A}}(81-113)-\mathrm{NH}_{2}(\# 305-24 \mathrm{D})$ [30] and 
cyclic acetyl human inhibin/activin $\beta_{\mathrm{B}}(81-113)-\mathrm{NH}_{2}$ (\#305-25D) [30] for $60 \mathrm{~min}$. Secondary incubation of the membranes was then carried out using a 1:1,000 dilution of goat anti-rabbit IgG tagged with horseradish peroxidase for $60 \mathrm{~min}$. Finally, the membranes were colored with $25 \mathrm{mg}$ of 3,3-diaminobenzidine (Wako, Tokyo, Japan) solution in 25 $\mathrm{m} l$ of TBS-T buffer $(0.02 \mathrm{M}$ Tris, $0.137 \mathrm{M} \mathrm{NaCl}$ and $0.1 \%$ Tween-20, pH 7.6) plus $3 \mu l$ of $\mathrm{H}_{2} \mathrm{O}_{2}$. The negative control lanes were incubated with the primary antibodies preabsorbed with an excess amount of the antigens.

Morphological observation of testicular and scented glandular tissues was performed for male muskrats during the breeding season (Fig. 2a). The histological conformations of testes and scented glands were both observed in the muskrats by hematoxylin-eosin staining (Fig. 2b, c). Leydig cells in interstitial components and Sertoli cells and all kinds of spermatogenic cells including spermatogonia, spermatocytes and elongate spermatids in seminiferous tubules were identified in testes of the muskrats (Fig. 2b). Glandular cells were the main cell type in the scented glandular tissues of the muskrats (Fig. 2c).

Immunoreactivity for inhibin $\alpha$ and inhibin/activin $\left(\beta_{\mathrm{A}}\right.$ and $\beta_{\mathrm{B}}$ ) subunits was present in testes and scented glands of the muskrats during the breeding seasons, respectively (Fig. $3)$. Immunolocalization of the inhibin $\alpha$ and inhibin/activin $\left(\beta_{\mathrm{A}}\right.$ and $\left.\beta_{\mathrm{B}}\right)$ subunits showed that they were not only in the cytoplasm of Leydig cells but also in the cytoplasm of Sertoli cells in testes of the muskrats during the breeding season (Fig. 3a, b, c). Positive immunostaining for inhibin $\alpha$ and inhibin/activin $\left(\beta_{\mathrm{A}}\right.$ and $\left.\beta_{\mathrm{B}}\right)$ subunits was also observed in the cytoplasm of glandular cells of scented glands of the muskrats during the breeding season (Fig. 3e, f, g). No immunostaining was detected in control sections of testes and scented glands in which normal rabbit serum was substituted for the primary antibody (Fig. 3d, h).

The results of Western blotting analysis for the inhibin $\alpha$ and inhibin/activin $\left(\beta_{\mathrm{A}}\right.$ and $\left.\beta_{\mathrm{B}}\right)$ subunits in the testes and scented glands during the breeding season are shown in Fig. 4. Positive signals of the inhibin $\alpha$ and inhibin/activin $\left(\beta_{\mathrm{A}}\right.$ and $\beta_{\mathrm{B}}$ ) subunits were detected in protein extracted from testes during the breeding season in the muskrats (Fig. 4a, b, c, lane 1). Immunodetection of the inhibin $\alpha$ and inhibin/ activin $\left(\beta_{\mathrm{A}}\right.$ and $\left.\beta_{\mathrm{B}}\right)$ subunits showed that they were also expressed in protein extracted from scented glands during the breeding season in the muskrats (Fig. 4a, b, c, lane 2). The protein lanes that were incubated with antibodies preabsorbed with an excess amount of the antigens were used for the negative control (Fig. 4a, b, c, lane 3). With the inhibin $\alpha$ or inhibin/activin $\left(\beta_{\mathrm{A}}\right.$ and $\left.\beta_{\mathrm{B}}\right)$ subunit antibody, the major bands detected in the testis or scented gland migrated to positions at about $55 \mathrm{kDa}$ and $30 \mathrm{kDa}$.

To our knowledge, this is the first study that describes immunolocalization of inhibin/activin subunits in testicular and scented glandular tissues of muskrats. The results of this study demonstrated the presence of inhibin/activin subunits in Sertoli cells and Leydig cells of testes and glandular cells of scented glands, respectively. These findings sug- gested that the muskrat testes and scented glands have the ability to synthesize inhibins and activins and that inhibins and activins might play an important role in testicular and scented glandular function in muskrats.

In the present study, the inhibin $\alpha$ and inhibin/activin $\left(\beta_{A}\right.$ and $\beta_{B}$ ) subunits were present in testicular tissues of the muskrats, showing that testicular tissues may secrete activins and inhibins in the breeding season. These findings are not unique to the muskrats, as similar observations had been found in other seasonal breeders, such as rams [15], Japanese black bears [31], raccoon dogs [32], ground squirrels [21] and stallions [16]. In rams, the presence of mRNA and protein of all three inhibin/activin subunits in adult testes was confirmed by Northern blot analysis and immunocytochemistry, respectively, showing that the testes could produce and secrete dimeric inhibin during the reproductive cycle [15]. In our studies on seasonal breeders [21, $31,32]$, positive staining for inhibin $\alpha, \beta_{\mathrm{A}}$ and $\beta_{\mathrm{B}}$ was observed in both Sertoli and Leydig cells in the breeding season, suggesting that Sertoli and Leydig cells of these seasonal breeders could secrete bioactive inhibins and activins in the breeding season. Previous studies suggested that inhibin/activin subunits might play some important roles in spermatogonial development $[13,28]$, such as Sertoli cell proliferation [2] and steroid biosynthesis [5, 6, 14]. Our results here are in agreement with previous studies indicating that inhibins and activins act as a paracrine or autocrine factor involved in spermatogenesis [23, 25]. The present findings indicate that the production of inhibins, and possibly activins, was dependent on the stage of the cycle of the seminiferous epithelium; these growth factors might cooperate with steroid hormones and play a paracrine/ autocrine role in the differentiation of spermatogenic cells.

In this study, inhibin/activin subunits were also present in glandular cells of muskrat scented glands during the breeding season, implying that inhibin and activin may be an autocrine or paracrine factor involved in modulating cells growth, differentiating and secreting function in scented glands of the muskrat. In normal human breast tissues, all three inhibin/activin subunits are localized in the ductal and lobular epithelial cells of the mammary glands, suggesting that ductal and lobular epithelial cells normally produce inhibin or activin-related peptides, possibly under regulatory mechanisms independent of menstrual cycle changes of circulating sex hormones [19]. A previous study of the reproductive tract concluded that activins are important factors that act at a local level to maintain appropriate cell-cell interactions, particularly in the testis and prostate [20]. Thus, the present results were in agreement with previous studies indicating that apart from their action on FSH secretion, inhibins or activins exert their effects through local (autocrine or paracrine) mechanisms, rather than through endocrine systems [20].

In the male, inhibins are produced in the testis, principally by the Sertoli cells. There are differences in inhibin expression and secretion depending on the species. In the stallion, golden hamster and $\operatorname{dog}$, the inhibin $\alpha, \beta_{\mathrm{A}}$ and $\beta_{\mathrm{B}}$ 

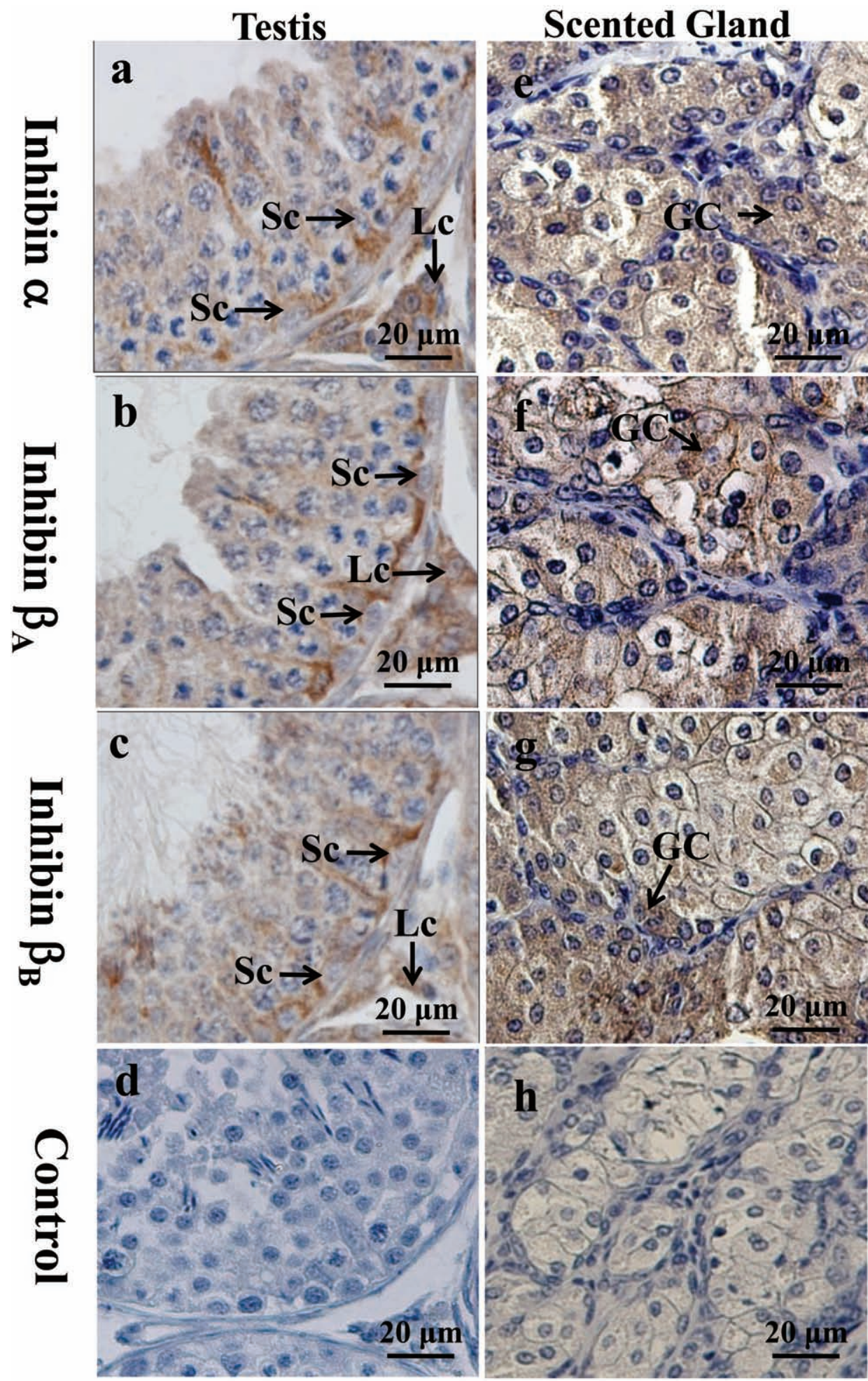

Fig. 3. Immunolocalization of the inhibin $\alpha$ and inhibin/activin $\left(\beta_{\mathrm{A}}\right.$ and $\left.\beta_{\mathrm{B}}\right)$ subunits in the testes and scented glands of the muskrats during the breeding seasons, respectively. Immunostaining for the inhibin $\alpha$ (a), inhibin/activin $\beta_{\mathrm{A}}$ (b) and inhibin/activin $\beta_{\mathrm{B}}$ (c) subunits was found in Leydig cells (Lc) and Sertoli cells (Sc) in the breeding season. Immunostaining for the inhibin $\alpha$ (e), and inhibin/activin $\beta_{\mathrm{A}}$ (f) and inhibin/activin $\beta_{\mathrm{B}}$ subunit (g) was present in glandular cells (GC) of scented glands in the breeding season. No immunostaining was detected in control testes and scented gland sections $(\mathrm{d}, \mathrm{h})$ in which normal rabbit serum was substituted for the primary antibody. Lc, Leydig cell; Sc, Sertoli cell ; GC, glandular cell. Bar: $20 \mu \mathrm{m}$. 
Inhibin $\alpha$

\section{0 kDa $130 \mathrm{kDa}$ \\ $95 \mathrm{kDa}$ \\ $72 \mathrm{kDa}$}

$55 \mathrm{kDa}$

36 kDa

$28 \mathrm{kDa}$

17 kDa

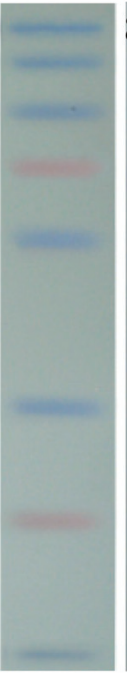

M

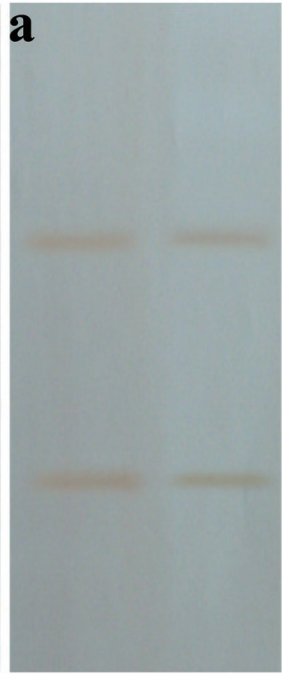

1

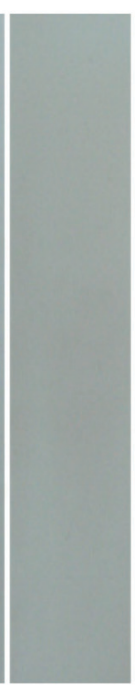

2

3

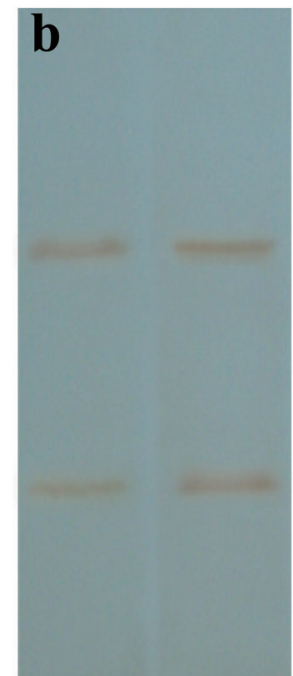

1

2
Inhibin $\beta_{A}$

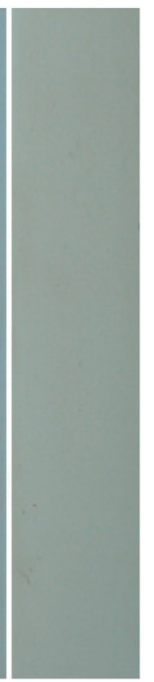

3

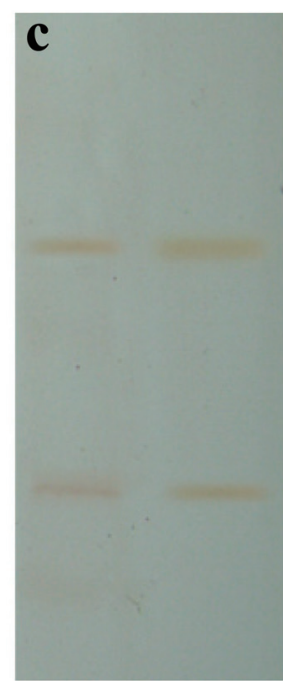

12
Inhibin $\beta_{B}$

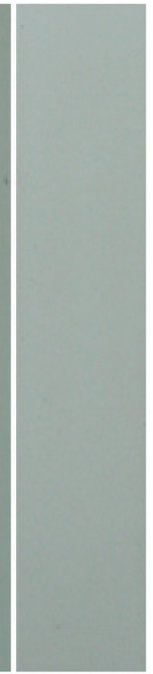

3

Fig. 4. Western blotting of the inhibin $\alpha$ and inhibin/activin $\left(\beta_{\mathrm{A}}\right.$ and $\left.\beta_{\mathrm{B}}\right)$ subunits in the testes and scented glands of the muskrats, respectively $(\mathrm{a}, \mathrm{b}, \mathrm{c})$. The left side shows the $12 \%$ range prestained SDS-PAGE standards (lane $\mathrm{M})$. Total protein was extracted from whole testicular tissue of the breeding season (lane 1) and whole scented glandular tissue of the breeding season (lane 2). Primary antibody reclaimed after full reaction was used for the negative control on the right side (lane 3).

subunits are present in both Sertoli and Leydig cells [10, 16, 24], and in adult monkeys, all three subunits are localized predominantly in Sertoli cells $[8,36]$. Previous studies showed that inhibin B is the major form of inhibins secreted from testes in men, Japanese macaques and Gottingen miniature pigs [7-9], but in the ram, inhibin A, and not inhibin $\mathrm{B}$, was produced in testicular tissues [15]. In the present study, inhibin $\alpha$ and inhibin $\left(\beta_{\mathrm{A}}\right.$ and $\left.\beta_{\mathrm{B}}\right)$ subunits were both expressed in testicular and scented glandular tissues, clearly indicating that apart from testicular tissues, the scented gland was an important source of inhibins in the muskrats. These results suggested that inhibin A and inhibin B could be secreted from testicular and scented glandular tissues. Interestingly, our experimental results for immunohistochemistry showed that P450c17 and P450arom were also detected in scented glands, implying that muskrat scented glands have the ability to synthesize androgen and estrogen (Qiang WENG). In our previous studies, P450scc, $\mathrm{P} 450 \mathrm{c} 17, \mathrm{P} 450$ arom and inhibin/activin $\beta_{\mathrm{B}}$ were observed in the equine fetal adrenal gland tissues, suggesting that inhibin/activin subunits and steroidogenic enzymes may play a physiological role in developing equine fetal adrenal glands [33, 34]. In another study, a relationship between testosterone and activin levels was reported in the process of cell proliferation in dog prostate glands. Testosterone also had a differential effect on inhibin $\alpha$ and $\beta$ subunits, and testosterone treatment led to predominant expression of $\beta_{\mathrm{A}}$ mRNA rather than $\alpha$ mRNA. Combined with the distribution and role of the inhibin/activin subunits, P450c17 and
P450arom in the scented glands of the muskrats, our results suggested that inhibin/activin subunits interacting with steroidogenic enzymes might cooperate with steroid hormones to play an autocrine or paracrine role in scented glandular function of muskrats during the breeding season. Future studies will be necessary to investigate inhibin and activin levels in the breeding and nonbreeding seasons and the pattern of inhibin/activin subunit expression in the nonbreeding season.

The authors are grateful to Dr. N. Ling (Neuroendocrine, San Diego, CA, U.S.A.) for providing [Tyr30] inhibin- $\alpha-(1-$ 30) and to Dr. W. Vale (Clayton Foundation for Peptide Biology, Salk Institute for Biological Studies, La Jolla, CA, U.S.A.) for providing antisera against the inhibin $\beta_{A}$ and $\beta_{B}$ subunits. This study was supported by a Grants-in-Aid from the Program for the Fundamental Research Funds for the Central Universities (BLYX200921), the Beijing Forestry University Young Scientist Fund (BLX2W8004) and the Changjiang Scholars and Innovative Research Team in Universities (IRT0607) from China.

\section{REFERENCES}

1. Ball, E. M. and Risbridger, G. P. 2001. Activins as regulators of branching morphogenesis. Dev. Biol. 238: 1-12.

2. Boitani, C., Stefanini, M., Fragale, A. and Morena, A. R. 1995. Activin stimulates Sertoli cell proliferation in a defined period of rat testis development. Endocrinology 136: 5438-5444.

3. Chen, C. L. 1993. Editorial: Inhibin and activin as paracrine/ autocrine factors. Endocrinology 132: 4-5. 
4. Chen, Y. S., Zhao, W. G., Zhao, M., Chang, Z. J., Zhang, Y. and Ma, D. W. 2007. Histological Observation on Musksecreting Scented Gland in Muskrat. Chin. J. Zool. 42: 91-95.

5. de Winter, J. P., Vanderstichele, H. M., Timmerman, M. A., Blok, L. J., Themmen, A. P. and de Jong, F. H. 1993. Activin is produced by rat Sertoli cells in vitro and can act as an autocrine regulator of Sertoli cell function. Endocrinology 132: 975-982.

6. Hsueh, A. J., Dahl, K. D., Vaughan, J., Tucker, E., Rivier, J., Bardin, C. W. and Vale, W. 1987. Heterodimers and homodimers of inhibin subunits have different paracrine action in the modulation of luteinizing hormone-stimulated androgen biosynthesis. Proc. Natl. Acad. Sci. 84: 5082-5086.

7. Illingworth, P. J., Groome, N. P., Byrd, W., Rainey, W. E., McNeilly, A. S., Mather, J. P. and Bremner, W. J. 1996. Inhibin-B: a likely candidate for the physiologically important form of inhibin in men. J. Clin. Endocrinol. Metab. 81: 13211325 .

8. Itoh, M., Kondo, M., Kojima, C., Jin, W., Watanabe, G., Taya, K., Hayashi, M. and Shimizu, K. 2003. Inhibin B is the major form of inhibin secreted from testes in male Japanese macaques (Macaca fuscata). Primates 44: 253-257.

9. Jin, W. Z., Arai, K. Y., Herath, C. B., Kondoh, M., Ishi, H., Tanioka, Y., Watanabe, G., Groome, N. P. and Taya, K. 2001. Inhibins in the male Gottingen miniature pig: Leydig cells are the predominant source of inhibin B. J. Androl. 22: 953-960.

10. Jin, W. Z., Wada, S., Arai, K. Y., Kishi, H., Herath, C. B., Watanabe, G., Suzuki, A. K., Groome, N. P. and Taya, K. 2001. Testicular secretion of inhibin B in the male golden hamster (Mesocricetus auratus). J. Androl. 22: 207-211.

11. La Rosa, S., Uccella, S., Marchet, S., Capella, C. and Lloyd, R. V. 2004. Localization of inhibins and activins in normal endocrine cells and endocrine tumors of the gut and pancreas: an immunohistochemical and in situ hybridization study. J. Histochem. Cytochem. 52: 217-225.

12. Lin, T., Calkins, H., Morris, P. L., Vale, W. W. and Bardin, C. W. 1989. Regulation of Leydig cell function in primary culture by inhibin and activin. Endocrinology 125: 2134-2150.

13. Mather, J. P., Attie, K. M., Woodruff, T. K., Rice, G. C. and Phillips, D. M. 1990. Activin stimulates spermatogonial proliferation in germ-Sertoli cell cocultures from immature rat testis. Endocrinology 127: 3206-3214

14. Mauduit, C., Chauvin, M. A., de Peretti, E., Morera, A. M. and Benahmed, M. 1991. Effect of activin A on dehydroepiandrosterone and testosterone secretion by primary immature porcine Leydig cells. Biol. Reprod. 45: 101-109.

15. McNeilly, A. S., Souza, C. J., Baird, D. T., Swanston, I. A., McVerry, J., Crawford, J., Cranfield, M. and Lincoln, G. A. 2002. Production of inhibin A not B in rams: changes in plasma inhibin A during testis growth, and expression of inhibin/activin subunit mRNA and protein in adult testis. Reproduction 123: 827-835.

16. Nagata, S., Tsunoda, N., Nagamine, N., Tanaka, Y., Taniyama, H., Nambo, Y., Watanabe, G. and Taya, K. 1998. Testicular inhibin in the stallion: cellular source and seasonal changes in its secretion. Biol. Reprod. 59: 62-68.

17. Noguchi, J., Hikono, H., Sato, S., Watanabe, G., Taya, K., Sasamoto, S. and Hasegawa, Y. 1997. Ontogeny of inhibin secretion in the rat testis: secretion of inhibin-related proteins from fetal Leydig cells and of bioactive inhibin from Sertoli cells. J. Endocrinol. 155: 27-34.

18. Onagbesan, O. M., Safi, M., Decuypere, E. and Bruggeman, V. 2004. Developmental changes in inhibin alpha and inhibin/ activin beta and betaB mRNA levels in the gonads during post- hatch prepubertal development of male and female chickens. Mol. Reprod. Dev. 68: 319-326.

19. Reis, F. M., Luisi, S., Carneiro, M. M., Cobellis, L., Federico, M., Camargos, A. F. and Petraglia, F. 2004. Activin, inhibin and the human breast. Mol. Cell. Endocrinol. 225: 77-82.

20. Risbridger, G. P. and Cancilla, B. 2000. Role of activins in the male reproductive tract. Rev. Reprod. 5: 99-104.

21. Sheng, X., Zhang, H. L., Zhang, W., Song, M. S., Zhang, M. Y., Li, B., Weng, Q., Watanabe, G. and Taya, K. 2008. J. Seasonal changes in spermatogenesis and immunolocalization of inhibin/activin subunits in the wild male ground squirrel (Citellus dauricus Brandt). Reprod. Dev. 54: 460-464.

22. Spencer, S. J., Rabinovici, J. and Jaffe, B. 1990. Human recombinant activin-A inhibits proliferation of human fetal adrenal cells in vitro. J. Clin. Endocrinol. Metab. 71: 16781680 .

23. Tanaka, Y., Taniyama, H., Tsunoda, N., Shinbo, H., Nagamine, N., Nambo, Y., Nagata, S., Watanabe, G., Herath, C. B., Groome, N. P. and Taya, K. 2002. The testis as a major source of circulating inhibins in the male equine fetus during the second half of gestation. J. Androl. 23: 229-236.

24. Taniyama, H., Hirayama, K., Nakada, K., Numagami, K., Yaosaka, N., Kagawa, Y., Izumisawa, Y., Nakade, T., Tanaka, Y., Watanabe, G. and Taya, K. 2001. Immunohistochemical detection of inhibin- $\alpha,-\beta \mathrm{B}$, and $-\beta \mathrm{A}$ chains and $3 \beta$-hydroxysteroid dehydrogenase in canine testicular tumors and normal testes. Vet. Pathol.. 38: 661-666.

25. Tena-Sempere, M., Kero, J., Rannikko, A., Yan, W. and Huhtaniemi, I. 1999. The pattern of inhibin/activin alpha- and betaB-subunit messenger ribonucleic acid expression in rat testis after selective Leydig cell destruction by ethylene dimethane sulfonate. Endocrinology 140: 5761-5770.

26. Vale, W., Rivier, C. and Hsueh, A. 1988. Chemical and biological characterization of the inhibin family of protein hormones. Recent. Prog. Horm. Res. 44:1-34.

27. Vale, W., Rivier, J., Vaughan, J., McClintock, R., Corrigan, A., Woo, W., Karr, D. and Spiess, J. 1986. Purification and characterization of an FSH releasing protein from porcine ovarian follicular fluid. Nature 321:776-779.

28. Van Dissel-Emiliani, F. M., Grootenhuis, A. J., de Jong, F. H. and de Rooij, D. G. 1989. Inhibin reduces spermatogonial numbers in testes of adult mice and Chinese hamsters. Endocrinology 125: 1899-1903.

29. Van, D. 1973. New macrocycle compounds for the secretions of the civet cat and the muskrat. Recuei 92: 9-15.

30. Vaughan, J. M., Rivier, J., Corrigan, A. Z., McCLintock, R., Jolley, D., Voglmayr, J. K., Bardin, C. W., Rivier, C. and Vale, W. 1989. Detection and purification of inhibin using antisera generated against peptide fragments. Methods. Enzymol. 168: 588-617.

31. Weng, Q., Medan, M. S., Okano, T., Tsubota, T., Xu, M. Y., Watanabe, G. and Taya, K. 2006. Changes in serum inhibin levels and immunolocalization of inhibin/Activin subunits during the breeding season in the wild male Japanese black bears (Ursus thibetanus japonicus). Endocrine 29: 345-350.

32. Weng, Q., Medan, M. S., Xu, M. Y., Tsubota, T., Watanabe, G. and Taya, K. 2006. Seasonal changes in immunolocalization of inhibin/Activin subunits and testicular activity in wild male raccoon dogs (Nyctereutes procynoides). J. Reprod. Dev. 52: 503-510.

33. Weng, Q., Tanaka, Y., Taniyama, H., Tunoda, N., Nambo, Y., Watanabe, G. and Taya, K. 2007. Immunolocalization of Steroidogenic Enzymes P450scc, 3betaHSD, P450c17, and 
P450arom in Fetal Adrenal Glands during Mid-Late Gestation of Equine. J. Reprod. Dev. 53: 1093-1098.

34. Weng, Q., Tanaka, Y., Taniyama, H., Tunoda, N., Nambo, Y., Watanabe, G. and Taya, K. 2007. Immunolocalization of Inhibin/Activin Subunits in Equine Fetal Adrenal Glands during Mid Gestation. J. Equine. Science. 18: 93-97.

35. Ying, S. Y., Zhang, Z., Furst, B., Batres, Y., Huang, G. and Li,
G. 1997. Activins and activin receptors in cell growth. Proc. Soc. Exp. Biol. Med. 214: 114-122.

36. Zhang, T., Zhou, H. M. and Liu, Y. X. 1997. Expression of plasminogen activator and inhibitor, urokinase receptor and inhibin subunits in rhesus monkey testes. Mol. Hum. Reprod. 3: 223-231. 